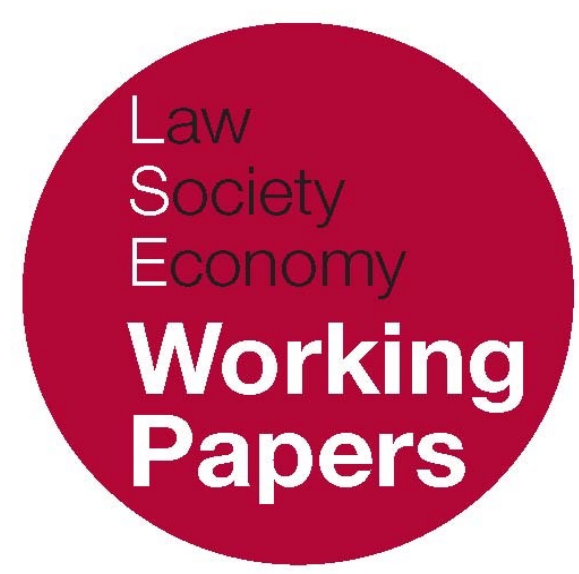

\title{
U.S. Constitutional Law, Proportionality, and the Global Model
}

\author{
Kai Möller \\ Forthcoming in Vicki Jackson and Mark Tushnet (eds.), Proportionality: New \\ Frontiers, New Challenges, Cambridge University Press, 2016 \\ LSE Law, Society and Economy Working Papers 06/2016 \\ London School of Economics and Political Science \\ Law Department
}

This paper can be downloaded without charge from LSE Law, Society and Economy Working Papers at: www.lse.ac.uk/collections/law/wps/wps.htm and the Social Sciences Research Network electronic library at: http://ssrn.com/abstract $=2747222$.

(C) Kai Möller. Users may download and/or print one copy to facilitate their private study or for non-commercial research. Users may not engage in further distribution of this material or use it for any profit-making activities or any other form of commercial gain. 


\title{
U.S. Constitutional Law, Proportionality, and the Global Model
}

\author{
Kai Möller
}

\begin{abstract}
Following the global success of the principle of proportionality in human and constitutional rights adjudication, there is now an emerging debate among academics and judges in the United States as to whether proportionality ought to be introduced into U.S. constitutional law. My goal in this paper is to correct what I see as a misleading simplification in this discussion, namely the view that the United States could introduce proportionality while leaving the other features and characteristics of its constitutional rights jurisprudence intact. I argue that if proportionality is adopted, coherence requires that the other features of what in previous work I have labelled "the global model of constitutional rights" be embraced as well: rights inflation, positive obligations, socio-economic rights, and horizontal effect. Thus, proportionality is not just an isolated standard of review but part and parcel of a conception of rights that must be adopted or rejected as a whole.
\end{abstract}

* Associate Professor of Law, Department of Law, London School of Economics and Political Science. 


\section{INTRODUCTION}

Following the global success of the principle of proportionality in human and constitutional rights adjudication, there is now an emerging debate among academics and judges in the United States as to whether proportionality ought to be introduced into U.S. constitutional law, ${ }^{1}$ where it would replace the current tiered system of scrutiny (rational basis, intermediate scrutiny, strict scrutiny) and various other standards of review. Certainly it must be true that the confusing variety of standards currently employed in U.S. constitutional law indicates a structural weakness, and proportionality with its one-size-fits-all approach seems to be a good choice to repair it. ${ }^{2}$ One of the advantages of proportionality is that it offers a framework which can indeed be applied to all (at least all non-absolute, negative) rights, but which is at the same time flexible enough to accommodate relevant differences and distinctions; for example, the concern currently expressed by the tiered system, namely that the intensity of review should vary depending on the subject matter at stake, can easily be integrated into the proportionality framework.

My goal in this paper is to correct what I see as a misleading simplification in this discussion, namely the view that the United States could introduce proportionality while leaving the other features and characteristics of its constitutional rights jurisprudence intact. I will argue that if proportionality is adopted, coherence requires that the other features of what in previous work I have labelled "the global model of constitutional rights" 3 be embraced as well: rights inflation, positive obligations, socio-economic rights, and horizontal effect. Thus, proportionality is not just an isolated standard of review but part and parcel of a conception of rights that must be adopted or rejected as a whole.

The paper has the following structure. In the next section I will introduce the global model of constitutional rights and also say something about how it relates to the current state of U.S. constitutional law. This will be followed by a brief account of the theory of rights that best justifies the global model. The third section will show that the adoption of proportionality inevitably leads to the necessity to endorse the other features of the global model as well. The Conclusion will offer some tentative reflections about the direction into which U.S. constitutional law would develop if it opened itself to proportionality.

\footnotetext{
${ }^{1}$ See in particular Stephen Breyer, Active Liberty: Interpreting Our Democratic Constitution (New York: Knopf, 2005), 49; Breyer, Making Our Democracy Work: A Judge's View (New York: Knopf, 2010), 163-171. Vicki C. Jackson, Constitutional Law in an Age of Proportionality, 124 (2015) Yale Law Journal 3094.

${ }^{2}$ For an argument to the effect that the quality of a court's jurisprudence will be determined more by the good judgment of the judges than by the quality of the legal or constitutional doctrines they use, see Mark Tushnet's contribution in Proportionality: New Frontiers, New Challenges (Cambridge University Press, forthcoming 2016).

${ }^{3}$ Kai Möller, The Global Model of Constitutional Rights (Oxford University Press, 2012).
} 


\section{THE GLOBAL MODEL OF CONSTITUTIONAL RIGHTS}

\section{The Dominant Narrative of the Philosophy of Fundamental Rights, AND U.S. CONSTITUTIONAL LAW}

The global model of constitutional rights is best introduced and explained by contrasting it with what I have called the "dominant narrative" of the philosophy of fundamental rights. The dominant narrative holds (1) that rights cover only a limited domain by protecting only certain especially important interests of individuals; (2) that rights impose exclusively or primarily negative obligations on the state; (3) that rights operate only between a citizen and his government, not between private citizens; and (4) that rights enjoy a special normative force which means that they can be outweighed, if at all, only in exceptional circumstances.

The dominant narrative will resonate with American constitutional lawyers. With regard to its first feature - rights as protecting only interests of special importance - there is an interesting parallel in U.S. constitutional law, where the question of which interests attract the protection of fundamental rights is intensely discussed in the context of the Due Process Clause of the 14th Amendment. This debate is dominated by two opposing camps, which, following Ronald Dworkin, I will refer to as the party of history and the party of integrity. ${ }^{5}$ The party of history argues that the Due Process Clause protects only interests 'deeply rooted in this Nation's history and tradition'; this view is not relevant to my inquiry here. By way of contrast, the party of integrity focuses squarely on moral criteria; however, its proponents have been struggling with the challenge of providing a test to determine whether an interest - say, in being able to choose abortion, use contraception, marry a partner of one's choice, or engage in homosexual sex — is important enough to qualify as a fundamental right. The following famous statement by Justices O'Connor, Kennedy, and Souter in Casey is maybe the most widely discussed attempt to capture what is at stake here:

These matters, involving the most intimate and personal choices a person may make in a lifetime, choices central to personal dignity and autonomy, are central to the liberty protected by the Fourteenth Amendment. At the heart of liberty is the right to define one's own concept of existence, of meaning, of the universe, and of the mystery of human life. Beliefs about these matters could not define the attributes of personhood were they formed under compulsion of the State. ${ }^{6}$

This is not the place to examine the issue in depth; suffice it to say that, first, American constitutional law does not simply regard any liberty interest as attracting

\footnotetext{
${ }^{4}$ Parts of this section draw on my book The Global Model of Constitutional Rights (see above n. 3).

${ }^{5}$ Ronald Dworkin, Sovereign Virtue: The Theory and Practice of Equality (Harvard University Press, 2000) 454 455.

6 Planned Parenthood v. Casey, 505 U.S. 833, 851 (1992).
} 
the protection of constitutional rights, and, second, for the party of integrity, the correct test that separates rights from mere liberty interests will involve some variation of the three Justices' statement and will thus presumably relate to how intimate or personal the choice in question is, or how central to dignity or autonomy. To this extent, the American approach is in line with the dominant narrative.

American constitutional law, furthermore, does not know a general doctrine of positive obligations and, like the dominant narrative, insists that rights create only or mainly negative obligations on the state. One example is DeShaney v, Winnebago County Department of Social Services, 7 decided by the U.S. Supreme Court in 1989. Joshua DeShaney was a little boy who was physically abused by his father. The Winnebago County Department of Social Services was aware of this but did not remove Joshua from his father's custody. Eventually Joshua was injured so badly that he suffered permanent brain damage and was rendered profoundly retarded. The constitutional question was whether by failing to protect him from his father, the State had violated his rights under the substantive component of the Due Process Clause. Rehnquist CJ, writing for the majority of the Court, denied this, providing two reasons for this conclusion. First, he argued that the language of the $14^{\text {th }}$ Amendment (' $[\mathrm{N}]$ or shall any State deprive any person of life, liberty, or property, without due process of law') indicated that it protected a person only against the state and that it could not fairly be understood to impose on the state a positive obligation to protect. ${ }^{8}$ Second, historically, the Due Process Clause was intended to prevent government 'from abusing [its] power, or employing it as an instrument of oppression... Its purpose was to protect the people from the State, not to ensure that the State protected them from each other'. ${ }^{9}$ While this case is not without criticism, ${ }^{10}$ it is still "good law" and stands for the general doctrine that constitutional rights are concerned with preventing governmental abuse of power and therefore do not generally create positive obligations.

Moving on to the third feature of the dominant narrative, in the United States, constitutional rights will only apply when there is "state action". Hence, just as under the dominant narrative, rights operate between a citizen and the state; they do not normally affect the private law relationships between persons. There are certain cases in U.S. constitutional law that do not sit easily with the state action doctrine, but they remain outliers. ${ }^{11}$

\footnotetext{
${ }^{7}$ DeShaney v. Winnebago County Department of Social Services, 489 U.S. 189 (1989).

8 Ibid., 195.

${ }^{9}$ Ibid., 196

${ }^{10}$ David A. Strauss, Due Process, Government Inaction, and Private Wrongs, 1989 Supreme Court Review 53.

${ }^{11}$ I have in mind Shelley v. Kraemer, 334 U.S. 1 (1948), and New York Times Co. v. Sullivan, 376 U.S. 254 (1964). On these cases and the issue of the state action doctrine, see Mark Tushnet, The Issue of State Action/Horizontal Effect in Comparative Constitutional Law, 1 (2003) International Journal of Constitutional Law 79; Stephen Gardbaum, Where the (State) Action Is, 4 (2006) International Journal of Constitutional Law 760.
} 
And finally, just as the dominant narrative, American constitutional law ascribes a special importance to fundamental rights, reflected in the fact that, at least as a matter of traditional doctrine, a strict scrutiny standard is applied to determine the permissible limitations of those rights, and as the saying goes, strict scrutiny is 'strict in theory and fatal in fact', 12 indicating that it is an uphill battle for a state to convince a court that a limitation of a fundamental right is justified. This reflects the intuition shared by philosophers of fundamental rights that rights have a special normative force and can be limited only in exceptional circumstances.

\section{The Global Model of Constitutional Rights}

Under the global model of constitutional rights, all four elements of the dominant narrative have been given up - and often a long time ago. The doctrines and developments in constitutional rights law which have led to their erosion are rights inflation, positive obligations and socio-economic rights, horizontal effect, and balancing and proportionality.

\section{a. Rights inflation}

Constitutional rights are no longer seen as only protecting certain particularly important interests. Especially in Europe a development has been observed which is sometimes pejoratively called "rights inflation", ${ }^{13}$ a name which I use in a neutral sense as describing the phenomenon that increasingly, relatively trivial interests are protected as (prima facie) rights. The European Court of Human Rights (ECtHR) routinely reads such interests into the right to private life (Article 8 of the European Convention on Human Rights [ECHR]). For example, in the famous Hatton case, which concerned a policy scheme that permitted night flights at Heathrow airport, thus leading to noise pollution that disturbed the sleep of some of the residents living in the area, the Court discovered as part of Article 8 the right not to be 'directly and seriously affected by noise or other pollution', ${ }^{14}$ dismissively dubbed "the human right to sleep well" by George Letsas. ${ }^{15}$ An even more extreme approach is that of the German Federal Constitutional Court, which has explicitly given up any threshold to distinguish a mere interest from a constitutional right. As early as 1957 it held that Article 2(1) of the Basic Law, which protects everyone's right to freely develop his personality, is to be interpreted as a right to freedom of action. ${ }^{16}$ The Court provided various doctrinal reasons for this result, its main argument being that an earlier draft of Article 2(1) had read 'Everyone can do as he pleases' ('Jeder kann tun und lassen was er will'), and

12 Gerald Gunther, The Supreme Court, 1971 Term - Foreword: In Search of Evolving Doctrine on a Changing Court: A Model for a Newer Equal Protection, (1972) 86 Harvard Law Review 1, 8.

${ }^{13}$ George Letsas, $A$ Theory of Interpretation of the European Convention on Human Rights (Oxford University Press, 2007), 126.

${ }^{14}$ Hatton v. United Kingdom, (2003) 37 EHRR 28, para. 96.

${ }^{15}$ Letsas above n. 13,126

16 BVerfGE 6, 32 (Elfes). 
that this version had been changed only for semantic reasons. ${ }^{17}$ The Court affirmed this ruling in various later decisions; most famously, it declared that Article 2(1) of the Basic Law included the rights to feed pigeons in a park ${ }^{18}$ and to go riding in the woods. ${ }^{19}$

\section{b. Positive Obligations and Socio-Economic Rights}

Rights are no longer regarded as exclusively imposing negative obligations on the state. But while most theorists of rights only started to reconsider their views on this issue following the growing acceptance of socio-economic rights (particularly their inclusion in the South African Constitution), human and constitutional rights law had given up the view that rights impose only negative obligations since the 1970s when the doctrine of positive obligations became established.20 The idea is that the state is under a duty to take steps to prevent harm to the interests protected by (otherwise negative) rights. Thus, the state must, as a matter of constitutional rights law, put in place a system which effectively protects people from dangers emanating from other private persons, such as criminal activities which threaten, for example, life, physical integrity, or property; and it must also protect them from dangers which do not have a (direct) human cause, such as natural disasters.

Furthermore, there is a trend towards the acknowledgement of socioeconomic rights which obviously impose positive obligations on the state and thus conflict with the dominant narrative according to which rights are concerned primarily with negative obligations. The most widely discussed example of this development is the South African Constitution, which contains in its sections 26, 27 and 29 rights to housing, health care, food, water, social security and education.

\section{c. Horizontal Effect}

Fundamental rights are no longer seen as affecting only the relationship between the citizen and the state; rather, they apply in some way between private persons as well. For example, the constitutional right to privacy may protect a person not only against infringements of his privacy by the state, but also against such infringements by his neighbour, landlord, or employer. The doctrinal tool which achieves this is called borizontal effect of rights, where "horizontal" as opposed to "vertical" indicates that rights operate between private persons. The first court to

${ }^{17}$ Ibid., 36-37.

18 BVerfGE 54, 143 (Pigeon-Feeding).

${ }^{19}$ BVerfGE 80, 137 (Riding in the Woods).

20 The ECtHR discovered positive obligations in the Belgian Linguistic case (No. 2) (1968) 1 EHRR 252, the German Federal Constitutional Court introduced them in its famous Abortion I decision (BVerfGE 39, 1) of 1975, and the Inter-American Court of Human Rights acknowledged them in its first major judgment, Velásquez-Rodríguez v. Honduras, Judgment of July 29, 1988. While these courts found positive obligations despite there being little or no textual support, the South African Constitution explicitly endorses them by stating in its section 7(2): “The state must respect, protect, promote and fulfil the rights in the Bill of Rights'. Here, "respect" refers to negative obligations, whereas "protect" refers to positive obligations. 
acknowledge horizontal effect was the German Federal Constitutional Court in its famous Lüth decision of 1953.21 From Germany the concept travelled to other parts of the world. It has by now become a well-established feature of the global model of constitutional rights; one indicator of its success is that the South African Constitution explicitly endorses horizontal effect in section 8(2), which states in slightly awkward language: 'A provision of the Bill of Rights binds a natural or a juristic person if, and to the extent that, it is applicable, taking into account the nature of the right and the nature of any duty imposed by the right'.

\section{d. Balancing and Proportionality}

Contrary to the dominant narrative, it is not the case that constitutional rights generally enjoy a special or heightened normative force in legal practice. While it is true that some rights are absolute — for example the right to freedom from torture - most rights, including the rights to life, physical integrity, privacy, property, freedom of religion, expression, assembly and association, can be limited in line with the proportionality test. Proportionality has become the central doctrine of contemporary constitutional rights law, and has been accepted by virtually every constitutional court in Central and Eastern Europe and is increasingly employed in Central and South American jurisdictions.22 The proportionality test has four prongs. First, a policy interfering with a right must pursue a legitimate goal; second, it must be a suitable means of furthering the achievement of the goal (suitability or rational connection); third, it must be necessary in that there must not be a less restrictive and equally effective alternative (necessity); and finally and most importantly, it must not impose a disproportionate burden on the right-holder (balancing or proportionality in the strict sense). Some courts have adopted tests that look slightly different on the surface; 23 however, what all tests have in common is that at their core there is balancing exercise where the right is balanced against the competing right or public interest, ${ }^{24}$ which implies that far from enjoying any special or elevated status over public interests, rights operate on the same plane as policy considerations.

\footnotetext{
${ }^{21}$ BVerfGE 7,198 (Lüth).

22 Alec Stone Sweet and Jud Mathews, Proportionality Balancing and Global Constitutionalism, (2008-9) 47 Columbia Journal of Transnational Law 72, 112.

${ }^{23}$ For a critical discussion of how to best construct the proportionality test, see chapters 2 to 5 by, respectively, Möller, Bilchitz, von Bernstoff and Yowell in Liora Lazarus, Christopher McCrudden, and Nigel Bowles (eds.), Reasoning Rights: Comparative Judicial Engagement (Oxford: Hart, 2014).

${ }^{24}$ It should be noted that the Canadian version of the proportionality test tends to read the balancing exercise into the earlier stages, which is criticized by Denise Réaume who argues that 'this question [the question of which of the values is more important], which has so often been disguised and hidden elsewhere in the steps of the Oakes test, or simply not been addressed, properly belongs at the end of the process, with the other steps serving simply to disqualify bad justificatory arguments and refine the ultimate contest'. See Denise Réaume, Limitations on Constitutional Rights: The Logic of Proportionality, (2009) University of Oxford Legal Research Paper Series, Paper No. 26/2009 at 26. Dieter Grimm makes essentially the same point in his Proportionality in Canadian and German Constitutional Jurisprudence, (2007) 57 University of Toronto Law Journal 383.
} 


\section{TheORISING THE Global Model}

The global model does not reflect the once uncontroversial idea that the point of constitutional rights is to limit government and keep it out of our lives: that idea cannot make sense of horizontal effect, positive obligations, and socio-economic rights. The point of constitutional rights under the global model is not to disable government; rather it is to enable every person to take control of his or her life. Constitutional rights protect the ability of persons to live their lives according to their self-conceptions; thus, they are based on the value of personal autonomy. ${ }^{25}$ For example, constitutional rights protect a person's right to engage in free speech, believe in and follow the precepts of her religion (important aspects of personal autonomy), control her private life (including her sexual and reproductive autonomy), to bodily integrity (partly a precondition and partly an element of personal autonomy), and so on. This focus on autonomy makes sense of the existence of horizontal effect and positive obligations: from an autonomy-based perspective, what matters is not who violates the right but rather the adequate protection of the interest at stake. It can furthermore explain the existence of socio-economic rights such as the rights to food, healthcare, or education, which protect the preconditions of autonomy.

What is the scope of protection offered by constitutional rights? Should they cover a narrow or a broad range of autonomy interests? The first feature of the global model (rights inflation) suggests that an approach which regards rights as prima facie protecting all of a person's autonomy interests — including those of trivial importance, such as feeding birds or riding in the woods (to exploit those famous German cases again) - sits best with the practice of constitutional rights law. Thus, the picture that emerges is that under the global model, all autonomy interests are protected as rights; however, this protection is not absolute or nearabsolute; rather, rights can be limited as long as the limitation is proportionate. This conception of rights presumably will strike many, including many American constitutional lawyers, as counter-intuitive. Is it possible to show it as morally coherent? It is indeed possible, but to do so, we must abandon a view held dearly by most if not all philosophers and many constitutional lawyers, who insist that fundamental rights protect only a narrow range of interests while having a special normative force which means that they can only exceptionally be outweighed by competing considerations. That model is flatly incompatible with the practice of constitutional rights law around the world, in particular with the global

\footnotetext{
25 This claim is consistent with the fact that the means used to protect autonomy will often be the limitation of state power. For example, the point of limiting the state's power to control a person's sex life is the need to respect his autonomy in sexual matters. This applies also to procedural rights such as the presumption of innocence: the protection of this right is necessary, for a variety of reasons, in order to adequately safeguard people's ability to autonomously live their lives, but the means used to achieve this is to limit the state's power to convict people to situations where they have been proven guilty.
} 
endorsement of the proportionality approach. Instead, I defend the following account of the point of constitutional rights under the global model. Each person's basic entitlement is to be treated with a certain attitude: an attitude that takes her seriously as a person with a life to live, and that will therefore deny her the ability to live her life in a certain way only when there are sufficiently strong reasons for this. Applied to the case of hobbies such as feeding the birds, this means that we should not ask whether the freedom to feed birds is an aspect of a narrowly defined set of especially important interests. Instead, we should ask whether the state treats a person subject to its authority in a way which is justifiable to her when it prohibits, for example, her participation in the activity of feeding birds; and this will be the case only when there are sufficiently strong reasons supporting the prohibition. Thus, the point of constitutional rights is not to single out certain especially important interests for heightened protection. Rather, it is to show a particular form of respect for persons by insisting that each and every state measure which affects a person's ability to live her life according to her selfconception must take her autonomy interests adequately into account in order to be justifiable to her. Constitutional rights law institutionalises a "right to justification", ${ }^{26}$ that is, a right to be provided with an adequate justification for every state action (and omission) that affects the agent's autonomy.

The two-stage analysis endorsed by constitutional rights law in almost all liberal democracies reflects this approach. The first question that constitutional rights lawyers ask is whether an act by a public authority has interfered with (limited, restricted) a right. If so, the duty of justification is triggered, and therefore, at the second stage of the inquiry the question is whether the interference can be justified, which is the case if it is proportionate. The point and purpose of the proportionality test is to provide a useful structure to the inquiry as to whether an act by a public authority is justifiable to the person affected by it. It does so by splitting up the question of justification into four subquestions that can be analysed separately.

\section{PROPORTIONALITY WITHOUT THE GLOBAL MODEL?}

This section argues that if U.S. constitutional law subscribes to proportionality, coherence requires that it also adopt the other features of the global model, that is, rights inflation, horizontal effect, positive obligations, and socio-economic rights. To demonstrate this point, I will show in the first subsection that proportionality necessitates rights inflation. The second subsection will demonstrate that it

\footnotetext{
26 On the idea of a moral human right to a justification see Rainer Forst, The Justification of Human Rights and the Basic Right to Justification: A Reflexive Approach, (2010) 120 Ethics 711. See further Mattias Kumm, The Idea of Socratic Contestation and the Right to Justification: The Point of Rights-Based Proportionality Review, (2010) 4 Law \& Ethics of Human Rights 141. On the idea of a culture of justification, see Moshe Cohen-Eliya and Iddo Porat, Proportionality and Constitutional Culture (Cambridge University Press, 2013), ch. 6.
} 
requires the acknowledgement of positive obligations and even social rights, as well as horizontal effect.

The argumentative strategy with regard to both subsections is that proportionality-based judicial review sees rights as being about and based on the right-holder's (autonomy) interests (as opposed to, for example, being about the limitation of the power of the state), ${ }^{27}$ and that this necessitates the acknowledgement of the other features of the global model. The point that rights are based on the right-holder's interests can be explained in the following way. A crucial feature of proportionality-based judicial review is that rights and interests operate on the same plane - hence they can be balanced against each other. For example, when the right to private life is limited in order to protect a public interest in national security, then under proportionality the clash between the right (private life) and the interest (national security) is (ultimately) resolved by balancing the two against each other. Thus, in contrast to conceptions of rights that regard them as normally taking precedence over competing interests (for example by operating as trumps ${ }^{28}$ or side constraints ${ }^{29}$ ), under proportionalitybased judicial review no such precedence exists; rather, rights and interests can unproblematically be compared and their relative importance be assessed. This implies that the normative force of a right amounts precisely to the importance of the interest(s) on which it is based.

The above point is also captured elegantly in Robert Alexy's famous theory of rights as principles. ${ }^{30}$ For Alexy, principles are optimisation requirements: they must be realised to the greatest possible extent. When principles clash, it follows as a matter of logic that proportionality analysis must be employed, and this means that optimising the principles at stake will usually involve balancing. Constitutional rights are principles, and hence they must be balanced against competing principles, for example public interests that the legislature can legitimately choose to protect. While I believe that Alexy's theory of balancing has its weaknesses, ${ }^{31}$ it nevertheless nicely illustrates that under proportionality-based judicial review, rights and principles operate on the same plane.

\section{Proportionality AND Rights INFLATION}

Presumably, American constitutional lawyers will not find it difficult to accept the argument made in this section, namely that proportionality requires embracing

\footnotetext{
27 See above n. 25 and accompanying text.

28 On rights as trumps, see Ronald Dworkin, Justice for Hedgehogs (Harvard University Press, 2011), ch. 15.

For an earlier statement of the same idea, see his A Matter of Principle (Harvard University Press, 1985), ch. 17 , especially 359-365.

29 On rights as side constraints, see Robert Nozick, Anarchy, State, and Utopia (Oxford: Blackwell Publishing, 1974), 29-30.

30 Robert Alexy, A Theory of Constitutional Rights (Oxford University Press, 2002).

31 See my Balancing and the Structure of Constitutional Rights, (2007) 5 International Journal of Constitutional Law 453 .
} 
rights inflation. The reason for this is that American constitutional law already embraces rights inflation under a different name: it is already the case, at least in theory, that any "liberty interest" receives constitutional protection and can only be limited when there is a rational basis for doing so. Thus, U.S. lawyers would structure the notorious German cases dealing with the rights to go riding in the woods and to feed pigeons in a park in the following way: first, they would ask whether a liberty interest is at stake, and having answered in the affirmative, they would consider whether there is a rational basis for the limitation of this interest. There are two differences between the American and the German approaches: German lawyers would apply proportionality and not the rational basis test at the second stage of the inquiry; and German lawyers would insist that the protected activity be labelled a "right", not just an "interest" because in Germany, Article 2(1) of the Basic Law is interpreted as providing a right to freedom of action. Thus, assuming that rational basis review would have been replaced with proportionality review, the only remaining doctrinal difference between the U.S. and the German approaches would be terminological.

There are good moral reasons to drop this terminological distinction between "liberty interests" and "rights" and accept that a person's rights protect not only certain especially important interests but indeed all his liberty interests. Consider the example of hobbies: collecting stamps, playing tennis, or riding in the woods. Although these hobbies may be reasonably important activities for the people engaging in them, they do not display crucial life decisions such as whether to procreate, whom to choose as a partner, or which profession to take up. Would it be possible to say that although hobbies have some importance, this importance is simply not great enough to attract the protection of constitutional rights? The idea would be to introduce a threshold of importance, and only interests that reach this threshold would be protected as constitutional rights. Any limitation of those rights would be permissible only if proportionate; in turn, an interest that did not reach the threshold would not be protected and could therefore be limited unrestrictedly. This model, the threshold model, can be contrasted with the comprehensive model, according to which any interest, however trivial, is sufficient to attract the protection of constitutional rights.

The comprehensive model is preferable. Its rival, the threshold model, would have to draw a line somewhere, stipulating that anything below that line falls foul of the necessary threshold and is therefore not protected. However, it is hard to see how such a threshold could be set in a non-arbitrary way. Would the interest have to be of reasonable, average, high, or fundamental importance? What should be the criteria here? The consequence of accepting a threshold at any specific level of importance would be that an interest that is just below the threshold receives no protection whatsoever, whereas an interest which is just above the threshold can only be interfered with in a proportionate manner. This difference in protection cannot be justified if all that separates the two interests is a tiny margin of importance: it is simply incoherent to attach such morally significant consequences to such a small difference in importance. To be sure, we might just 
draw the line somewhere in a pragmatic way and declare that from now on, only interests that are at least, say, "very" important are protected. But the defining feature of pragmatic approaches to moral questions is the absence of principle, and we are looking for a principled approach to limit the domain of constitutional rights; therefore, a pragmatic solution is not acceptable. It follows that the only possible conclusion is that the threshold requirement should be dropped and it should be acknowledged that every liberty interest should be protected as a constitutional right.

The above point is reflected in the practice of human and constitutional rights law. While we cannot know with certainty why, as a matter of history and psychology, courts have been so hesitant to embrace threshold conceptions of rights, it is plausible to assume that they have been guided by two considerations. The first is that they find it impossible to articulate a principled threshold, and that they feel uncomfortable about stipulating an arbitrary one, which leaves them only the option to take a generous approach to the scope of rights and embrace, or at least accept, rights inflation. The second is that judges have understood much earlier than philosophers of rights that, both descriptively and normatively speaking, the central issue in reasoning about rights is not whether a given interest is protected as a right. Rather, the issue that dominates judicial review is whether a limitation of a right is supported by sufficiently strong reasons. The focus of constitutional rights adjudication is on the second stage of rights analysis; and hence judges will be inclined not to develop any doctrines, let alone incoherent ones, regarding the first stage if they can resolve the case in a coherent and principled way at the second stage, namely by examining whether there are sufficiently strong reasons for the limitation of the interest at stake. Imagine you are a constitutional judge who has to decide a case regarding someone's wish to feed birds in a park. One possibility is to dismiss the case on the ground that there is no right to feed birds; but this would require you to develop at least the rough outline of a threshold theory delineating protected from unprotected interests, and you have no idea how to formulate this threshold (because it cannot be formulated in a coherent way). Your other option is to accept a right to feed birds and move on to the second stage of the analysis, where you examine whether the limitation of this right is justified. This will be much more satisfactory for two reasons: first, psychologically speaking, it allows you to do what you feel comfortable and confident about, namely assessing the strength of justifications. Second, morally speaking, it does justice to both case and applicant because rather than relying on arbitrary thresholds, it focuses on the substantive justifiability of the state act in question. 


\section{Proportionality, Socio-Economic Rights, Positive Obligations, AND HORIZONTAL EFFECT}

U.S. constitutional law does not know a general doctrine of positive obligations flowing from constitutional rights; to give just one example, the Supreme Court denied in the above-mentioned DeShaney case that the 14th Amendment creates a positive obligation on the state to protect children from physical abuse by their parents. Under the global model, DeShaney would not necessarily have had a different outcome, but the court would have structured its inquiry in a different way. It would have argued in a first step that the right to physical integrity creates not only negative but also positive obligations on the state, in particular obligations to protect. In a second step, it would have assessed whether the state complied with this obligation. The ECtHR uses a "reasonable steps" test ${ }^{32}$ to determine the state's obligations under the Convention. Thus, the question would have been whether the state took the steps that it could reasonably have been expected to take; in the DeShaney case, it would seem that the failures of the social workers concerned with the case were so grave that applying the ECtHR's test, Joshua would probably have won his case.

The endorsement of positive obligations is, I believe, unavoidable under proportionality-based judicial review, and therefore, if U.S. constitutional law adopts proportionality, coherence requires that it also accept positive obligations. This can be explained in the following way. At the core of the proportionality test is the balancing stage, where the right-holder's interests are balanced against the public interests at stake. Put differently, the question is whether the interests of the right-holder are burdened to a greater extent than she can be expected to bear. Thus, proportionality-based judicial review is concerned with the adequate protection of the right-holder's interests. Adequately protecting a person's interests requires more, however, than simply abstaining from state intervention: often an adequate protection of a person's interests will require the state to become active; thus, positive obligations and socio-economic rights become necessary. The DeShaney case is an example in point: from Joshua's perspective, his primary concern is not who harmed him (the state or his father) but rather that his interest in physical integrity was disrespected. It would be incoherent to first accept - as one does when one subscribes to proportionality-based judicial review - that what matters is an adequate protection of a person's interests, and then to require the state only to abstain from interference with the interest as opposed to also protecting it.

\footnotetext{
${ }^{32}$ See, for example, Osman v. United Kingdom (2000) 29 EHRR 245, 305:
}

In the opinion of the Court where there is an allegation that the authorities have violated their positive obligation to protect the right to life in the context of their above-mentioned duty to prevent and suppress offences against the person, it must be established to its satisfaction that the authorities knew or ought to have known at the time of the existence of a real and immediate risk to the life of an identified individual or individuals from the criminal acts of a third party and that they failed to take measures within the scope of their powers which, judged reasonably, might have been expected to avoid that risk. 
The above point finds support in the case law of the ECtHR. The existence of both negative and positive obligations has become so commonplace that the Court often does not even bother to determine which kind of obligation is at stake in a given case. The Hatton case concerning night flights at Heathrow airport is again a good example. Given that the UK government had allowed the night flights, one could have argued that this was a case involving negative obligations (the UK interfering with the private life of the residents); however, given that Heathrow airport was run by a private company, it could also be constructed as being about a positive obligation (the UK failing to adequately regulate private industry). The Court does not resolve this issue but simply notes that

[w] hether the case is analysed in terms of a positive duty on the State to take reasonable and appropriate measures to secure the applicants' rights under para. 1 of Art. 8 or in terms of an interference by a public authority to be justified in accordance with para. 2, the applicable principles are broadly similar. In both contexts regard must be had to the fair balance that has to be struck between the competing interests of the individual and of the community as a whole... ${ }^{33}$

This approach makes immediate sense under a proportionality-based approach to rights adjudication which is concerned with the adequate protection of the rightholder's interests: what matters for the outcome of the case is not whether it involves negative or positive obligations. Rather the crucial aspect is whether the balance between the right-holder's interests and the public interests at stake has been struck in an adequate ("fair") way; and hence, the Court does not waste any time discussing the irrelevant issue of whether the case is about negative or positive obligations but goes straight to the important question of whether the applicant's interests have been protected adequately.

A parallel point applies to socio-economic rights: those rights are not only consistent with an understanding of rights that regards them as based on the rightholder's interests, but they are actually required by it: an adequate protection of a person's interests requires also the availability of basic goods such as food, water, housing, or healthcare. Therefore, under an approach which, like proportionality, is concerned with a person's interests, the acknowledgment of socio-economic rights is unavoidable.

Finally, the same logic applies to horizontal effect of rights. The doctrine of horizontal effect means that constitutional rights influence the private law relations between individuals. For example, the constitutional right to privacy has an impact on the relationships between landlord and tenant in that it will require the landlord to respect his tenant's privacy; this will be achieved by directing a judge in a legal dispute between the two parties to interpret the applicable private

33 Hatton v. United Kingdom, (2003) 37 EHRR 28, para. 98. 
law in light of the constitutional right to privacy, thus ensuring adequate respect for the right. Under proportionality-based judicial review which focuses on giving adequate protection to the interests of each person, it is easy to see why horizontal effect is needed: a person's interests can be under threat from another private party just as much as from the state; in this regard, horizontal effect is structurally related to, or arguably indeed a subcategory of, positive obligations. If we regard the interest protected by the right as an aspect of a person's life which is constitutionally protected, then it is important that private law, too, pay adequate respect to this interest.

Note that my concern in this paper is not to comprehensively defend positive obligations, social rights, or horizontal effect. First, I leave open the question of whether it would be possible to spell out a coherent theory of rights that is only or mostly concerned with limiting the power of the state. All I am saying is that if such a theory exists, it is incompatible with proportionality. Second, the above argument is not a comprehensive defence of the constitutional protection of positive obligations, socio-economic rights, or horizontal effect under a proportionality-based approach to judicial review because it focuses on the theory of rights underlying proportionality and leaves institutional considerations out of the picture. The main disagreement about socio-economic rights today is not so much whether they exist as a matter of morality; there is an emerging consensus to the effect that they do. Rather, the controversial question regarding the judicial enforcement of social rights is whether courts are in a good institutional position to adjudicate them. I cannot resolve that question here. My point is only that a commitment to proportionality will, as a matter of the underlying theory of rights, also necessitate a commitment to socio-economic rights. Thus, someone denying the necessity of protecting social rights at the constitutional level must show that the institutional problems with having courts involved in social rights adjudication are so severe that they justify excluding social rights from the scope of judicially enforceable rights. Maybe such a view can be defended successfully, ${ }^{34}$ but this would not affect the validity of my argument in this section.

\section{CONCLUSION}

This paper argued that the current discussion about proportionality in U.S. constitutional law is unduly narrow: under a morally coherent conception of constitutional rights, embracing proportionality requires the adoption of the other features and doctrines of the global model of constitutional rights, namely rights inflation, positive obligations, socio-economic rights, and horizontal effect.

\footnotetext{
${ }^{34}$ I have doubts regarding the view that considerations regarding the institutional competence of courts are of primary importance in constitutional interpretation because I lean towards Alon Harel's point that the point of judicial review is not to bring about desirable outcomes but rather the institutionalisation of a right to a hearing that is justified independently of those outcomes. See Harel, Why Law Matters (Oxford University Press, 2014), ch. 6.
} 
I repeatedly referred to the requirements of coherence in this paper. A sceptic might reply to my argument that U.S. constitutional law by and large has shown no great hesitation about endorsing morally incoherent doctrines - it has grown organically over decades and centuries, and this has arguably enabled it to preserve a certain amount of flexibility and pragmatism, at the cost of even the attempt, both of judges and largely also of scholars, at constructing a coherent system of thought. Thus, the objection could be that should U.S. constitutional law decide one day to adopt proportionality, it might continue to reject rights inflation, positive obligations, socio-economic rights, and horizontal effect, and it would not necessarily be bothered by this incoherence, just as it is not bothered by many other instances of incoherence that its constitutional jurisprudence displays. This may be true; and while I do not regard it as my task to predict the future, I will nevertheless point out the possibility that, should U.S. constitutional law adopt proportionality, over time it would be pushed towards the acceptance of the other features and doctrines of the global model as well. As I have stressed several times in this paper, the promise of proportionality is that a person's interests must always be taken adequately into account (hence a limitation is permissible only if it is proportionate). It is only a small step from this point to the further insight that proportionality is inherently geared towards assessing whether an act by a public authority is based on a good faith attempt at justice. Thus, a proportionality-based approach to judicial review is less about historical and doctrinal particularities of the respective constitution, and more about a substantive assessment of whether the authority acted with the right attitude, namely one that tries seriously and in good faith to bring about a just outcome. ${ }^{35}$ This promise requires the acceptance of the other features of the global model: rights inflation (because justice is concerned also with trivial matters), positive obligations and socio-economic rights (because justice also requires the state to become active), and horizontal effect (because justice makes demands on private law as well as public law). It is certainly a possibility that proportionality would be the site where this simple and attractive idea would be tested, adapted, and developed in the context of American constitutional law, before, should it be found to be worthwhile, it would begin to affect and influence the interpretation of other doctrines of U.S. constitutional law as well.

\footnotetext{
35 See Mattias Kumm, above n. 26 at 142: 'Instead of attempting to make sense of authoritative legal materials the focus of courts engaged in proportionality analysis is the assessment whether a public action can be demonstratively justified by reasons that are appropriate in a liberal democracy. Call this the turn from legal interpretation to public reason oriented justification.' (Emphasis in the original).
} 